Marzena Lemanowicz

Szkoła Glówna Gospodarstwa Wiejskiego w Warszawie

\title{
Rola promocji w kreowaniu wizerunku regionu - instrumenty, narzędzia, trendy. Przykład województwa świętokrzyskiego
}

\section{THE ROLE OF PROMOTION IN CREATING THE IMAGE OF A REGION - INSTRUMENTS, TOOLS, TRENDS. THE EXAMPLE OF THE ŚWIĘTOKRZYSKIE VOIVODESHIP}

\begin{abstract}
$W$ artykule zaprezentowano teoretyczne aspekty zwiazane z marketingiem terytorialnym, koncentrujqc się w szczególności na instrumencie jakim jest promocja. Wspótcześnie pojęcie promocji jest bardzo szerokie $i w$ ramach jej mamy możliwość wykorzystania różnych narzędzi, zarówno tych tradycyjnych jak $i$ niestandardowych. Popularność tych ostatnich wynika $w$ dużej mierze ze zmian w zachowaniach konsumentów spowodowanych chociażby rozwojem Internetu, a $w$ tym portali społecznościowych, blogów itp. Pojęcie promocji, marki, wizerunku jest dzisiaj używane $w$ odniesieniu nie tylko do towarów, firm, ale również miejsc, a więc regionów, miast, województw czy gmin.

Celem niniejszego artykulu jest przedstawienie szerokiego spectrum działań promocyjnych jakie zostały zrealizowane $w$ województwie świętokrzyskim, określenie rezultatów tych działań $w$ aspekcie ilościowym a także wizerunkowym. Ponadto zbadano poziom rozpoznawalności kampanii promocyjnych i ich zwiqzek analizowanym regionem. Aby zrealizować powyższe cele przeprowadzono badanie przy użyciu internetowego kwestionariusza ankiety. Grupe badawczq stanowiło 238 respondentów pochodzacych z całej Polski, którzy dobrowolnie wypetnili kwestionariusz. Wyniki badań potwierdzaja potrzebe prowadzenia działań promocyjnych $w$ regionach, gdyż działania te przyczyniaja się do kreowania wizerunku regionu, zwiększenia liczby osób odwiedzajacych dany region, a pomimo dużego „szumu informacyjnego” dziatania te sq zapamiętywane przez odbiorców.
\end{abstract}

Słowa kluczowe: marketing terytorialny, promocja turystyczna, wizerunek miejsca, marka miejsca, województwo świętokrzyskie

\section{Wstęp}

Pojęcie marki, wizerunku przez wiele lat kojarzone było głównie z produktem (towarem lub usługą) lub przedsiębiorstwem. Dopiero powstanie marketingu terytorialnego zwróciło uwagę naukowców, przedsiębiorców, osób zarządzających jednostkami samorządu terytorialnego na pojęcie marki w odniesieniu do obszaru. Proces kreowania marki czy to $\mathrm{w}$ odniesieniu do produktów czy miejsc jest procesem długotrwałym i wymagającym ponoszenia wysokich nakładów finansowych. Aby $\mathrm{z}$ powodzeniem wdrażać koncepcję marketingu terytorialnego, promocja nie może być postrzegana jako zbędny wydatek $\mathrm{z}$ budżetu. Negatywne nastawienie społeczeństwa czy też brak świadomości o potrzebie promocji, w wielu przypadkach doprowadza do tego, że władze 
samorządowe nie podejmują działań promocyjnych lub ograniczają się do podstawowych (wręcz standardowych) kampanii promocyjnych. Na promocji niestety nie można „oszczędzać”, gdyż najlepsze efekty przyniosą wyłącznie odpowiednio zaplanowane działania promocyjne, które potraktuje się jako inwestycję w rozwój regionu. Pojawia się zatem pytanie, w jaki sposób przeprowadzać działania marketingowe mające na celu zbudowanie wizerunku regionu, jeśli problemy pojawiają się już na szczeblu lokalnym. Tym bardziej, że pojedyncza kampania nie zmieni sposobu odbierania regionu w oczach potencjalnych turystów, mieszkańców, czy też inwestorów. Aby pomóc $\mathrm{w}$ przełamaniu tego niekorzystnego podejścia trzeba ustalić, jaką rolę pełni promocja turystyczna $w$ tworzeniu wizerunku regionu. Jeśli rola ta okaże się znacząca, możliwe będzie rozpowszechnienie koncepcji marketingu terytorialnego jako współczesnego narzędzia zarządzania regionem, które może przynieść pozytywne skutki zarówno dla mieszkańców, jak i władz samorządowych oraz potencjalnych turystów, mieszkańców i inwestorów.

\section{Promocja jako element marketingu terytorialnego}

Koncepcja marketingu terytorialnego powstała stosunkowo niedawno i obecnie jest w Polsce w fazie dynamicznego rozwoju. Pojęcie to poruszało dotychczas wielu autorów podkreślając, że jest to nowa nauka, koncepcja klasycznego marketingu przeniesiona na nowe obszary, dla której punktem wyjścia jest przestrzeń. Panasiuk ${ }^{1}$ podaje, że zjawisko to pojawiło się w końcu lat 80. XX wieku, co spowodowane było rosnącą konkurencją nie tylko ze strony produktów i przedsiębiorstw, ale całych obszarów (np. gmin). Marketing terytorialny, nazywany również marketingiem miejsca lub przestrzeni, to nowa koncepcja zarządzania rozwojem przestrzennym ${ }^{2}$, jest to całokształt działań marketingowych z użyciem zintegrowanego zespołu instrumentów, mający na celu podniesienie konkurencyjności danego miejsca oraz zaspokojenie potrzeb i pragnień mieszkańców ${ }^{3}$. Szromnik podkreśla jeszcze, że marketing terytorialny zmierza do wymiany wartości i wzajemnego oddziaływania wszelkich zaangażowanych podmiotów, a także opiera się na racjonalnym wykorzystywaniu istniejących zasobów.

W uproszczeniu, istota marketingu terytorialnego opiera się na tych samych elementach co klasyczny marketing. Skoro więc u podstaw marketingu terytorialnego leżą te same idee co w tradycyjnym marketingu można powiedzieć, że gmina funkcjonuje podobnie jak przedsiębiorstwo ${ }^{4}$ : władze regionu (odpowiednik przedsiębiorcy), chcą przyciagnąć turystów, inwestorów, nowych mieszkańców (klientów) do swojego regionu (który stanowi odpowiednik produktu).

Marketing terytorialny dysponuje wieloma narzędziami (marketing mix). Jednostki samorządu terytorialnego mogą stosować narzędzia wchodzące w skład

\footnotetext{
${ }^{1}$ A. Panasiuk: Marketing ustug turystycznych. Wyd. Naukowe PWN, Warszawa 2007, s. 70-73

P. Rumpel, T. Siwek: Marketing terytorialny a kreowanie regionów: przyklad czeski. „Przegląd Geograficzny". Wyd. PAN IGiPZ, 2006, t. 78, z. 2, s. 2

3 A. Szromnik: Marketing terytorialny jako atrybut rynkowej orientacji miast oraz regionów. [w:] A. Grzegorczyk (red.), A. Kochaniec (red.): Kreowanie wizerunku miast. Wyższa Szkoła Promocji, Warszawa 2011, s. 19

4 A. Brelik: Marketing terytorialny a kreowanie regionów. Zeszyty Naukowe Polityki Europejskie, Finanse i Marketing. Wyd. SGGW, 2010 nr 3 (52), s. 323
} 
koncepcji 4P (produkt, cena, dystrybucja i promocja), ale w przypadku marketingu terytorialnego istnieją pewne ograniczenia, ponieważ nie wszystkie elementy klasycznej koncepcji marketingu-mix mają $\mathrm{w}$ nim zastosowanie. Koncepcja $4 \mathrm{P}$ wiąże się $\mathrm{z}$ odpowiednią konfiguracją cech produktu, ustaleniem polityki cenowej, właściwym doborem miejsca, sposobu i czasu oferowania produktu oraz z dopasowaniem form i środków promocji. Należy jednak podkreślić, że ta koncepcja skierowana jest przede wszystkim do przedsiębiorstw oferujących dobra i usługi oraz zorientowanych na osiagganie zysków. Ponadto w przypadku Jednostek Samorządu Terytorialnego (JST) formuła 4P będzie stwarzać ograniczenia, między innymi dlatego, że opiera się na punkcie widzenia oferenta (a nie klienta), jako podstawę oferty zakłada jednakowy typ produktu i jednostronne stosunki informacyjno-promocyjne $\mathrm{z}$ rynkiem ${ }^{5}$.

W związku z tym, że działania samorządów terytorialnych przybierają najczęściej formę niematerialną i różnorodna, przez co zbliżone są do usług, postanowiono poszerzyć koncepcję 4P o dodatkowe elementy, takie jak: pracownicy/ludzie (people), cechy fizyczne (physical environment) i procesy (processes) ${ }^{6}$. Działalność samorządów terytorialnych sprowadza się również do tworzenia korzystnych warunków do współpracy, nawiązywania trwałych więzi z klientem i prowadzenia marketingu partnerskiego. Zasadnym wydaje się więc uwzględnienie w marketingu terytorialnym również koncepcji 4D, na którą składa się: efektywne zarządzanie bazą danych o klientach (database management), ukierunkowany marketing bezpośredni (dedicated direct marketing), projektowanie strategiczne (strategic design) i zróżnicowanie (differentation) ${ }^{7}$.

W warunkach rosnącej konkurencji między jednostkami terytorialnymi coraz trudniejsze staje się przyciagnięcie turystów, inwestorów czy mieszkańców, w związku z czym czynności podejmowane przez JST w celu osiagnięcia przewagi konkurencyjnej przybierają na większym znaczeniu. Muszą one spotęgować działania dotyczące zaspokajania potrzeb i pragnień klientów, a żeby tego dokonać niezbędne jest zbudowanie właściwego systemu informacji o ofercie i korzyściach związanych z jej nabyciem ${ }^{8}$. Oznacza to konieczność komunikacji między danym obszarem a jego otoczeniem (wewnątrz i na zewnątrz danej jednostki administracyjnej), co stanowi jeden z podstawowych elementów promocji.

Promocja jest jednym z elementów klasycznej koncepcji marketingowej, a jej podłoże stanowi potrzeba informacji, zarówno ze strony podaży jak i popytu. Polega ona na pozyskiwaniu klientów poprzez stosowanie zróżnicowanych środków promocji. Promocja jest także odpowiedzią na pytanie ,jak sprawić, by ludzie byli świadomi istnienia danego produktu i zdecydowali się na jego zakup ${ }^{9}$. Kołomycew ${ }^{10}$ podkreśla,

\footnotetext{
${ }^{5}$ Furman W.: Public relations - skuteczny instrument budowy wizerunku jednostki terytorialnej, w: K. Kaszuba (red.) Marketing w zarzadzaniu rozwojem lokalnym, Białystok: Fundacja Kształcenia Kadr, 2010. s. 60

${ }^{6}$ K. Lazorko (red.), A. Niedzielska (red.): Kreowanie wizerunku miejsca w koncepcji marketingu terytorialnego. Seria Monografie nr 207. Wyd. Politechniki Częstochowskiej, Częstochowa 2011, s. 14

${ }^{7}$ W. Furman, op.cit... s.63

8 G. Sobczyk, A. Celoch: Marketing wspótczesnej organizacji. [w:] D. Filar (red.): Wspótczesny marketing. Skuteczna komunikacja i promocja. Wyd. UMCS, Lublin 2012, s. 152

${ }^{9}$ M. Chrząścik: Teoretyczne ujęcie promocji $w$ aspekcie koncepcji marketingu terytorialnego. Zeszyty Naukowe Uniwersytetu Przyrodniczo-Humanistycznego w Siedlcach. Seria „Administracja i Zarządzanie”. Wyd. Uniwersytetu Przyrodniczo - Humanistycznego w Siedlcach, 2012 Nr 94, s. 6-7
} 
że promocja jest pojęciem węższym niż komunikacja marketingowa (do której zalicza również produkt, cenę i dystrybucję) i nie powinna być z nią utożsamiana. Instrumenty promocji to współcześnie nie tylko reklama, sprzedaż osobista, promocja sprzedaży, public relations czy marketing bezpośredni. Lena Malacka ${ }^{11}$ przedstawiła kompozycję narzędzi promocji (a w zasadzie komunikacji marketingowej) w podziale na tzw. nowe i stare narzędzia, przy czym do nowych zaliczyła: event marketing, marketing interaktywny, wystawy i targi, online marketing, WOM marketing. Klasyczne narzędzia promocji zostały dogłębnie opisane $\mathrm{w}$ literaturze związanej $\mathrm{z}$ przedmiotem badań dlatego też nie będą opisywane w niniejszym artykule. Poniżej kilka słów o wybranych nowoczesnych narzędziach mających zastosowanie w budowaniu marki miejsca.

City placement i event marketing. City placement to udostępnienie różnego rodzaju jednostek samorządu terytorialnego w celu przeprowadzenia na ich terenie komercyjnych przedsięwzięć artystycznych (szczególnie filmowych) w powtarzalnej i utrwalonej postaci w zamian za ich promowanie w sposób bezpośredni lub pośredni. Ten środek promocyjny stanowi innowację marketingową w zakresie komunikacji rynkowej jednostek terytorialnych ${ }^{12}$. Jednym $\mathrm{z}$ kierunków rozwoju city placement jest angażowanie miasta $\mathrm{w}$ organizowanie tzw. eventów. Zazwyczaj sa to prestiżowe wydarzenia o charakterze masowym, przez co ich lokalizacja może przynieść znaczące korzyści finansowe i marketingowe dla danego miejsca ${ }^{13}$. Co więcej, takie wydarzenie przekształca się w wizytówkę danego regionu. Przykład może stanowić Sabat Czarownic organizowany w Kielcach od 2010 do 2015 roku. Było to widowisko inscenizacyjnomuzyczne organizowane i transmitowane w TVP, którego fabuła, klimat oraz scenografia nawiązywały do legendarnych sabatów na Łysej Górze w Górach Świętokrzyskich. Na scenie podczas Sabatu Czarownic występowało wielu piosenkarzy i zespołów muzycznych.

Kotler umiejscawia event marketing wśród narzędzi promocji sprzedaży ${ }^{14}$, natomiast Florek uznaje event marketing za osobliwą formę public relations zawierającą liczne elementy sponsoringu ${ }^{15}$. Event marketing ma za zadanie oddziaływać na odbiorców poprzez autentyczne i bezpośrednie doświadczenia powstające podczas organizowanych $\mathrm{w}$ danym miejscu wydarzeń o charakterze masowym. Ta forma promocji ma na celu kreowanie i wzmacnianie wizerunku marki miejsca.

Targi. Jedną z największych korzyści, jakie przynoszą targi, jest bezpośrednia możliwość kształtowania pozytywnego wizerunku danej jednostki oraz popularyzacja miasta, regionu, kraju. Kolejne korzyści to: możliwość zaprezentowania oferty,

\footnotetext{
10 A. Kołomycew: Promotion in the agenda of public administration (the case of the communes in the Tarnobrzeg district). „Polityka i Społeczeństwo”. Wyd. Uniwersytetu Rzeszowskiego, 2010 nr 7, s. 2

${ }^{11}$ L. Malacka: Current trends in marketing communication and their application to Tourism https://www.researchgate.net/publication/277304941_CURRENT_TRENDS_IN_MARKETING_COMMUNI CATION_AND_THEIR_APPLICATION_TO_TOURISM (dostęp: 15.09.2017)

${ }^{12}$ A. Szromnik: Strategia city placement w systemie innowacji marketingowych - cz. 1. „Marketing i Rynek”. Wyd. PWE, $2015 \mathrm{nr} 8$, s. 6

${ }^{13}$ K. Peszko: Event marketing jako efektywne narzędzie komunikacji marketingowej. Zeszyty Naukowe Uniwersytetu Ekonomicznego w Poznaniu. Wyd. Uniwersytetu Ekonomicznego w Poznaniu, 2010 nr 136, s. $164-172$

${ }^{14}$ Ph. Kotler: Marketing Management, Analysis, Planning, Implementation and Control. Wyd. Prentice Hall, Englewood Cliffs, Nowy Jork 1994 s. 614

${ }^{15}$ M. Florek: Podstawy marketingu terytorialnego. Wyd. Akademii Ekonomicznej, Poznań 2006, s.156
} 
prowadzenia rozmów i negocjacji z potencjalnymi kontrahentami oraz możliwość otrzymania i zebrania informacji (np. w formie folderów i katalogów). Zmierzenie wszystkich korzyści związanych $\mathrm{z}$ udziałem w targach jest bardzo skomplikowane. Wynika to z ich kompleksowego charakteru, często niewymiernego i efektów, które nie zawsze pojawiają się od razu, tylko z pewnym opóźnieniem (po targach) ${ }^{16}$.

Internet jako narzędzie komunikacji marketingowej. Zwiększająca się odporność konsumentów na tradycyjne bodźce i przekazy, spowodowała, że powstało wiele nowych form komunikacji marketingowej. Nowe technologie pojawiające się w marketingu zmuszają przedsiębiorstwa (a także JST) do kreatywnego podejścia i wymyślania jak najskuteczniejszych sposób na dotarcie do klientów. Wśród najnowszych form i narzędzi komunikacji marketingowej wymienić można guerilla marketing, mobile marketing, viral marketing, WOM czy też buzz marketing. Poza tym na znaczeniu zyskały także media społecznościowe, takie jak Facebook, YouTube, Instagram, Twitter, czaty, blogi itp ${ }^{17}$.

WOM (ang. word-of-mouth), czyli marketing szeptany jest sposobem przekazywania informacji i rekomendacji o ofercie przez konsumentów, którzy już ją wypróbowali, innym potencjalnym konsumentom. Nie jest to nowa forma komunikacji w marketingu, ale odżyła i nabrała znaczenia w środowisku internetowym, przekształcając się w eWOM (ang. electronic word-of-mouth). Często zdarza się, że wywołuje znacznie lepsze efekty niż planowane działania marketingowe. Wynika to z tego, że WOM oraz rekomendacje od znajomych i rodziny uważane są za najbardziej wiarygodne źródło informacji przez $92 \%$ konsumentów na całym świecie ${ }^{18}$. Sprawdza się to również w turystyce, gdyż osobiste doświadczenia i opinie są dla potencjalnych turystów ważniejsze niż ogólne informacje zdobyte w Internecie. Oczywiście marketing szeptany może rozprzestrzeniać też negatywne opinie, przez co może okazać się bardzo niekorzystny dla danego przedsiębiorstwa czy JST .

Guerilla marketing, inaczej marketing partyzancki, opiera się głównie na wykorzystaniu niekonwencjonalnych i nietradycyjnych praktyk, umożliwiających osiagnięcie wysokiej skuteczności przekazu przy niskich kosztach w porównaniu do klasycznych narzędzi komunikacji marketingowej. W Internecie przekaz guerilla marketing można $\mathrm{z}$ łatwością rozpowszechniać poprzez social media (tj. blogi i media społecznościowe) .

Marketing wirusowy (ang. viral marketing) wywołuje podobne efekty jak wykorzystanie przekazu ustnego w WOM czy buzz marketing. W tym przypadku jednak przekaz jest rozpowszechniany w Internecie, przez co jest bardziej dynamiczny. Ta forma promocji funkcjonuje dzięki nieformalnemu, samodzielnemu przepływowi informacji pomiędzy internautami ${ }^{19}$. Kluczowym działaniem jest analiza przebiegu

\footnotetext{
${ }^{16}$ A. Szromnik: Targi w rozwoju miast i regionów. [w:] H. Mruk (red.): Znaczenie targów dla rozwoju gospodarczego kraju. Wyd. PIPT, Poznań 2011, s. 37-57

C. Castronovo, L. Huang: Social media in an alternative marketing communication model. „Journal of Marketing Development and Competitiveness". Wyd. North American Business Press, 2012, Vol. 6, No. 1, S. 6

${ }^{18}$ S. Santos: 2012 \& 2013 social media and tourism industry statistics. www.stikkymedia.com/blog/20122013-social-media-and-tourismindustry-statistics (dostęp 15.09.2017)

19 M. Gębarowski: Nowoczesne formy promocji. Wyd. Oficyna Wydawnicza Politechniki Rzeszowskiej, Rzeszów 2007, s. 103
} 
kampanii z użyciem tego narzędzia - należy kontrolować, kiedy konsumenci uzyskują dostęp do strony kampanii wirusowej, czy też śledzić liczbę odniesień i udostępnień przekazu przez konsumenta swoim przyjaciołom ${ }^{20}$.

Mobile marketing jest jedną z najnowszych form komunikacji marketingowej, która zaczyna zyskiwać na popularności. Umożliwia rozszerzenie zasięgu poza tradycyjne media i bezpośrednie oraz szybsze dotarcie do określonych odbiorców oraz zachęcenie konsumentów do podjęcia natychmiastowych działań po obejrzeniu reklam. Kampanie mobilne pomagają w budowaniu bazy klientów i lepszym zrozumieniu ich potrzeb, co z kolei przekłada się na możliwość opracowania wysoce ukierunkowanych kampanii ${ }^{21}$. Mobile marketing może przybrać formę powiadomień SMS lub MMS, WAP (ang. Wireless Application Protocol), infolinii IVR (ang. Interactive Voice Response), kodów 2D (np. QR code), kuponów i loterii, videostreamingu czy advergamingu. Marketing mobilny zapewnia możliwość wykorzystania sieci społecznościowych w celu zwiększenia zainteresowania. Według Truong i Simmons, konsumenci są bardziej skłonni do korzystania z urządzeń mobilnych, w celu uzyskania dostępu do portali społecznościowych. Narzędzie to może okazać się wysoce skuteczne w branży turystycznej, jeśli wziąć pod uwagę, że przykładowo $23 \%$ dorosłych Amerykanów wykorzystuje smartfony do nawigacji lub do wyszukiwania interesujących miejsc i atrakcji względem ich aktualnej pozycji ${ }^{22}$. Podobnie 30\% Kanadyjczyków pozostaje online w czasie wakacji, a $64 \%$ z nich używa smartfonów, aby uzyskać dostęp do informacji w Internecie. W związku z tym, połączenie mobilnego dostępu z mediami społecznościowymi może być używane do bezpośredniej komunikacji i targetowania określonych segmentów konsumentów ${ }^{23}$.

Trendy w marketingu zmieniają się nieustannie. Spośród tych najnowszych wymienić można wirtualną rzeczywistością czy real-time marketing, ale istnieją również kierunki rozwoju marketingu, funkcjonujące już od kilku lat, do których możemy zaliczyćc ${ }^{24}$ :

$$
\begin{aligned}
& \text { - } \quad \text { przekształcenie marketingu masowego w zindywidualizowany, } \\
& \text { ekspansja działań rynkowych na cyberprzestrzeń, } \\
& \text { skupienie się na zatrzymaniu klientów, a nie ich jednorazowym } \\
& \text { przyciagnięciu, } \\
& \text { przejście od komunikacji jednostronnej, do dialogu z klientami, } \\
& \text { modyfikacja nastawienia na produkcję i sprzedaż w nastawienie na } \\
& \text { klienta i jego emocje, }
\end{aligned}
$$

\footnotetext{
${ }^{20}$ C. Castronovo, L. Huang: Social media in an alternative marketing communication model. „Journal of Marketing Development and Competitiveness". Wyd. North American Business Press, 2012, Vol. 6, No. 1, s. 6

${ }_{21}$ M. Ferris: Insights on mobile advertising, promotion, and research. „Journal of Advertising Research”, 2007, Vol. 47, No. 1, s. 28-37

${ }^{22}$ K. Zickuhr, A. Smith: $28 \%$ of american adults use mobile and social location-based services. www.pewinternet.org/2011/09/06/28-of-american-adults-use-mobile-and-social-location-based-services/ (dostęp 15.09.2017)

${ }^{23}$ Y. Truong, G. Simmons: Perceived intrusiveness in digital advertising: Strategic marketing implications. „Journal of Strategic Marketing”. Wyd. Taylor \& Francis, 2011, Vol. 18, No. 3, s. 9

${ }^{24} \mathrm{Ph}$. Kotler, Philip Kotler odpowiada na pytania na temat marketingu, Dom Wyd. Rebis, Poznañ 2004, s.3334
} 
- $\quad$ dostrzeżenie znaczenia marki i jej wizerunku w świadomości konsumentów.

W przypadku trendów dotyczących bezpośrednio marketingu terytorialnego, zaobserwować można, że wzrosło zainteresowanie monitorowaniem działalności marketingowej prowadzonej przez JST. Na znaczeniu zyskuje partnerstwo publicznoprywatne i co-branding, czyli współpraca JST z przedsiębiorstwami prywatnymi i łączenie się ich marek, co możliwe jest tylko poprzez koordynację działań marketingowych wielu podmiotów. Ponadto samorządy coraz częściej korzystają z usług agencji marketingowych przy tworzeniu strategii promocji i wspieraniu niektórych zadań. Coraz częściej wykorzystywane są nowoczesne narzędzia promocji takie jak: advergaming - czyli połączenie reklamy z grą, geolokalizacja, która pozwala na prowadzenie działań marketingowych z użyciem gier lokalizacyjnych i reklamy na urządzeniach mobilnych, czy brand storytelling czyli mapowanie marki.

\section{Kreowanie marki miejsca - tożsamość i wizerunek miejsca}

Szeroki wachlarz możliwych do zastosowania narzędzi marketingowych jest wykorzystywany zazwyczaj w konkretnym celu. Z punktu widzenia JST tym celem może być wykreowanie marki danego obszaru i zbudowanie pozytywnego wizerunku danego obszaru. Wiadomym jest, że realizacja tych celów przyniesie efekty w postaci wzrostu liczby turystów odwiedzających region, napływu inwestorów, a także wzrost zadowolenia mieszkańców z zamieszkiwania na danym obszarze. Klasyczne definicje marki można odnieść również do marki terytorialnej, gdyż omawianym produktem czy też ofertą, w tym wypadku byłoby całe miasto czy dany region. Marka terytorialna stanowi kombinację elementów materialnych, takich jak infrastruktura techniczna, zagospodarowanie turystyczne, architektura i zabytki, oraz niematerialnych, takich jak wartości czy skojarzenia. Wszystko to składa się na autentyczność danego miejsca, jego tożsamość i kreowany na podstawie jej odbioru wizerune $\mathrm{k}^{25}$. W większości przypadków wizerunek miejsc stanowią stereotypy i uproszczenia rzeczywistości, często nieprawdziwe. Dlatego tak ważne jest odpowiednie budowanie tożsamości i kreowanie wizerunku miejsca.

Zaczęto dostrzegać, że silna marka terytorialna niesie ze sobą wiele korzyści, chociażby takich jak budowanie więzi i lojalności wobec miejsca. Ponadto wzmacnia ona pozycję miejsca na rynku usług turystycznych oraz zwiększa stopień jego znajomości i rozpoznawalności, a także atrakcyjności. To wszystko przekłada się na wzrost obłożenia bazy noclegowej i gastronomicznej oraz zmniejszenie sezonowości Stworzenie marki rozpoznawalnej, odnoszącej sukcesy i posiadającej korzystny wizerunek jest jednak długotrwałe i niełatwe.

$\mathrm{Z}$ pojęciem marki nierozerwalnie wiąże się pojęcie tożsamości (ang. brand identity, corporate identity) i wizerunku (ang. brand image). Pojęcia te często są utożsamiane, co jest błędem. Tożsamość miejsca i jego wizerunek to główne składowe marki miejsca i nie należy ich ze sobą mylić. Podstawową różnicę stanowi relacja

${ }^{25}$ S. Dudek-Mańkowska, A. Balkiewicz-Żerek: Siła marki miejsca. „Marketing i Rynek”. Wyd. PWE, 2015 nr 6, s. 14-23 
zachodząca między nimi, ponieważ odbiór tożsamości kreuje określony wizerunek. Relację tę przedstawiono na rysunku nr 1.

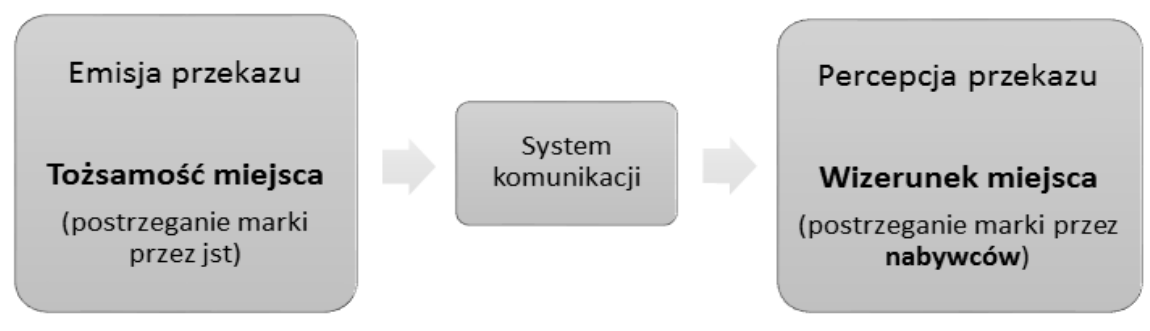

Rysunek 1. Relacja pomiędzy tożsamością a wizerunkiem Źródło: Opracowanie własne

Władze JST mogą w zaplanowany sposób zbudować tożsamość, tak aby odzwierciedlała pożądany sposób postrzegania miejsca. Jest to element dynamiczny, przez co można go aktywnie kształtować, wywołując w efekcie oczekiwaną reakcję ze strony odbiorców i osiagnięcie zamierzonych celów (np. przekonanie turysty do odwiedzenia danego miejsca) ${ }^{26}$. Tożsamość jest więc sposobem postrzegania marki przez władze JST (podmioty odpowiedzialne za jej tworzenie), zaś wizerunek miejsca to sposób postrzegania marki przez odbiorców (np. turystów, mieszkańców, inwestorów, organizacje). W marketingu terytorialnym może się zdarzyć, że pomiędzy tożsamością a wizerunkiem pojawią się rozbieżności. Może to wynikać z istniejących wcześniej stereotypów oraz doświadczeń odbiorców z przeszłości. Mają na to wpływ także niewystarczające działania związane z komunikowaniem tożsamości ze strony władz oraz tworzenie się doświadczeń i opinii nieadekwatnych do kreowanej tożsamości. Kreowanie tożsamości miejsca opiera się na trzech filarach ${ }^{27}$ :

- zachowaniach, na które składają się zachowania i działania podejmowane przez różne podmioty działające w określonym miejscu (mieszkańcy, władze miejskie, instytucje),

- $\quad$ identyfikacji wizualnej rozumianej jako kreowanie systemu prezentacji i identyfikacji za pomocą systemu symboli i oznaczeń,

- $\quad$ komunikacji z otoczeniem rozumianej jako system komunikacji miejsca $\mathrm{z}$ otoczeniem, przekazujący informacje na temat jego walorów, atrakcji, produktów.

Fundamenty wizerunku stanowi wyraźna tożsamość, ale poza tym wpływa na niego wiele czynników. Przede wszystkim, jako że wizerunek jest przefiltrowanym mentalnym odpowiednikiem rzeczywistości, głównym elementem kształtującym go jest sam człowiek. Baloglu i McCleary ${ }^{28}$, w oparciu o przegląd dotychczasowej literatury,

\footnotetext{
${ }^{26}$ A. Aleksander, A. Sworowska: Kształtowanie tożsamości jako element działań marketingowych regionu. [w:] J. Koszałka (red.): Marketing. Ujęcie Terytorialne. Wyd. Katedra Marketingu, Wydział Zarządzania i Ekonomii, Politechnika Gdańska, Gdańsk 2010, s. 62

27 S. Dudek-Mańkowska, A. Balkiewicz-Żerek, op. cit..., za E.Glińska, M.Florek i A.Kowalewska: Wizerunek miasta: od koncepcji do wdrożenia, Wolters Kluwer, Warszawa 2009

${ }^{28}$ S. Baloglu, K.W. McCleary, A model of destination image formation, "Annals of Tourism Research" 1999 , nr 26(4), s. 868-897.
} 
opracowali model powstawania wizerunku miejsca. Autorzy wyróżnili dwie grupy czynników, wpływających na powstawanie wizerunku miejsc: indywidualne cechy jednostek (personal factors) oraz czynniki zewnętrzne(external stimulus factors).

Do pierwszej grupy czynników zaliczyli oni cechy społeczno-demograficzne (np. wiek, poziom wykształcenia, status materialny) i psychologiczne (wartości, motywacje oraz osobowość jednostki). Za czynniki zewnętrzne uznano doświadczenia osoby związane z danym miejscem oraz źródła informacji, z których jednostka czerpie wiedzę o danym miejscu.

\section{Koncepcja programu promocji i budowy marki regionu świętokrzyskiego}

W Strategii Rozwoju Turystyki Województwa Świętokrzyskiego na lata 2014-202029, jednym z kluczowych obszarów jest „Zintegrowany marketing regionu i efektywna komunikacja marketingowa". Celem realizowanym w tym obszarze jest prowadzenie efektywnych działan marketingowych dla marki i produktów turystycznych województwa oraz osiagnięcie efektywnego poziomu współpracy i integracji w zakresie komunikacji marketingowej pomiędzy partnerami rynku turystycznego. W ramach tego obszaru wyznaczono 4 cele operacyjne:

1. Kontynuację budowy rozpoznawalnej i silnej marki województwa o wyróżniającym się wizerunku

2. Efektywne wsparcie promocyjne produktów turystycznych

3. Uruchomienie specjalnych projektów promocyjnych

4. Budowę i wdrożenie marketingowej Platformy Współpracy pomiędzy partnerami rynku

Działania z zakresu promocji i budowy marki regionu podjęto znacznie wcześniej. W perspektywie finansowej 2007-2013 Regionalnego Programu Operacyjnego Województwa Świętokrzyskiego" przewidziana została możliwość dofinansowania pierwszej spójnej kampanii promocyjnej dla całego regionu. W ramach osi priorytetowej 2. Wsparcie innowacyjności, budowa spoleczeństwa informacyjnego oraz wzrost potencjatu inwestycyjnego regionu, działania 2.3 Promocja gospodarcza i turystyczna regionu zrealizowane zostały cztery komplementarne merytorycznie projekty promocyjne: „Kampania promocyjna województwa świętokrzyskiego”, „Wykreowanie i promocja markowych produktów turystycznych Województwa Świętokrzyskiego oraz ich kompleksowe oznakowanie”, „Turystyczna promocja Regionu Świętokrzyskiego poprzez produkcje audiowizualne, PR, reklamę oraz inne nowoczesne instrumenty i narzędzia” oraz „Poprawa wizerunku turystycznego regionu poprzez promocję walorów wczesnobarokowego zamku Krzyżtopór w Ujeździe” Beneficjentem pierwszych trzech projektów była Regionalna Organizacja Turystyczna Województwa Świętokrzyskiego organizacja odpowiedzialna za promocję regionu. Kampania promocyjna województwa świętokrzyskiego realizowana była zgodnie z założeniami "Strategii rozwoju turystyki w województwie świętokrzyskim na lata 2006-2014". Wypracowano materialne przedstawienie marki - logo oraz uzupełniające go hasło. Proponowanymi motywami

\footnotetext{
${ }^{29}$ Strategia rozwoju turystyki w województwie świętokrzyskim na lata 2014-2020, http://www.rot.swietokrzyskie.travel (dostęp: 25.09.2017)
} 
wiodącymi dla Świętokrzyskiego stały się: „Świętokrzyska czarownica” i „Moc”, które sięgają do zasobów kulturowych regionu, lokalizują produkt w przestrzeni oraz prezentują główne korzyści, jakie oferowane są odbiorcom. Województwo jest kreowane na region magiczny i tajemniczy, co w przekazie składa się na hasło promocyjne „Świętokrzyskie czaruje - poleć na weekend!” oraz logo województwa świętokrzyskiego - charakterystyczną literę „S’" odzwierciedlającą czarownicę. Zarówno w kampanii promocyjnej, jak i komplementarnych wobec niej działaniach po jej zakończeniu, motywem przewodnim, spójnym dla wszystkich działan, stał się motyw świętokrzyskiej czarownicy. $\mathrm{Na}$ rysunku 1 przedstawiono logo województwa świętokrzyskiego.

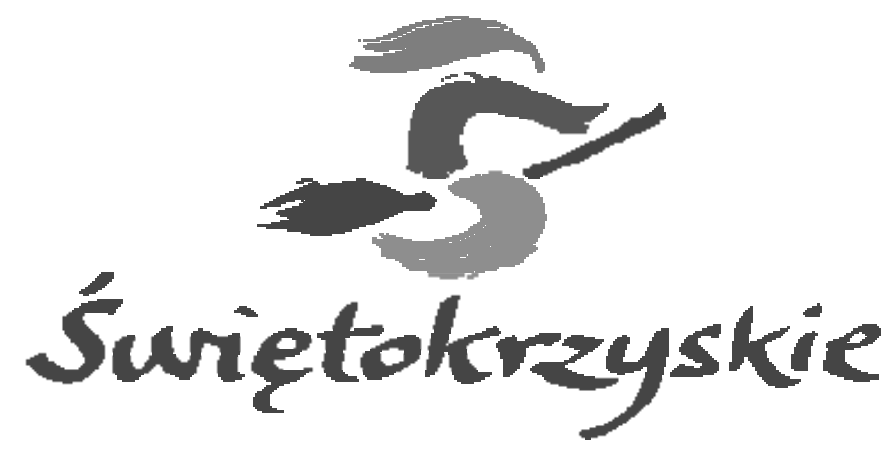

Rysunek 2. Logo województwa świętokrzyskiego

Źródło: http://www.rot.swietokrzyskie.travel (25.09.2017)

Najważniejsze działania promocyjne, które udało się zrealizować w województwie to:

1. Stworzenie pierwszego $\mathrm{w}$ regionie Zintegrowanego Systemu Informacji Turystycznej w warstwie analogowej (sieć centrów i punktów informacji turystycznej).

2. Stworzenie pierwszego w regionie Cyfrowego Systemu Informacji Turystycznej Województwa Świętokrzyskiego. System składa się z głównego portalu regionalnego dostępnego $w$ różnych wersjach językowych (www.swietokrzyskie.travel) i dziesięciu portali lokalnych, prezentujących dane z subregionów (odpowiadających swoim zasięgiem powiatom).

3. Uczestnictwo w krajowych i zagranicznych targach turystycznych (m.in. w Londynie, Kijowie, Budapeszcie, Berlinie, Moskwie, Bratysławie czy Utrechcie). Od 2012 r. promocję regionu na targach wzbogaca rewolucyjny projekt, mianowicie mobilne stoisko o ciekawej i funkcjonalnej formie „Czarująca Kapsuła”, zaś od 2013 r. drugi pojazd - „Odlotowa Kapsuła 5D”. „Czarująca Kapsuła” to mniejszy pojazd stanowiący przestrzeń do spotkań, rozmów i prezentacji materiałów promocyjnych, takich jak filmy reklamowe i prezentacje audiowizualne. „Odlotowa Kapsuła 5D” to kino 5D, dzięki któremu uczestnicy targów mogą „przenieść” się do województwa świętokrzyskiego. Pojazd umożliwia prezentację walorów regionu $\mathrm{w}$ nietypowy sposób i przyciaga duże zainteresowanie zarówno ze strony turystów, jak i mediów. 
4. Organizacja imprez promocyjnych (m.in. cykl imprez pod wspólną nazwą „Świętokrzyski Festiwal Mocy”).

5. Organizacja wizyt studyjnych dla dziennikarzy z Polski i zza granicy, przedstawicieli biur podróży oraz inwestorów z branży turystycznej.

6. Przeprowadzanie kampanii reklamowych w telewizji, prasie, radiu i Internecie. Promocję w telewizji rozpoczęto już w 2008 roku i kontynuowano w następnych latach. Spoty reklamujące region pojawiły się w wielu stacjach telewizyjnych (TVN, TVN Turbo, TVI Style, TVP2, Polsat), często w tzw. prime time. Kampania w Internecie była realizowana na portalu Onet.pl oraz w mediach społecznościowych. Efektem pierwszego etapu kampanii było około 1500 wejść dziennie na portal regionu.

7. Przygotowanie wydawnictw promocyjnych

8. Umiejscowienie regionu $\mathrm{w}$ różnych produkcjach filmowych (Ojciec Mateusz, Świętokrzyskie Sztetle, Gabriel)

Jednakże nie wszystko zostało zrealizowane według założeń. Wg oceny eksperckiej oraz prac warsztatowych w subregionach zdiagnozowano główne problemy związane $\mathrm{z}$ podjętymi działaniami promocyjnymi. Pierwszy problem to brak skomercjalizowanej oferty turystycznej regionu $\mathrm{w}$ postaci sprzedażowych pakietów dostępnych u touroperatorów w regionie i poza regionem. Problem drugi to słaba dostępność regionu i jego atrakcji turystycznych, w tym zrealizowanych z funduszy UE inwestycji oraz brak wystarczającej ilości flagowych atrakcji w istniejących centrach turystycznych. Kolejny problem to niewystarczający poziom profesjonalizacji kadr i powiązany $\mathrm{z}$ tym niski prestiż ,zawodów turystycznych”, a także niewystarczająca spójność w działaniach marketingowych - brak nawiązywania ,,parasola marki” w działaniach podejmowanych przez część interesariuszy na różnych poziomach. Zaistniałe problemy uwzględniono w strategii rozwoju województwa do 2020 roku. Dlatego też nadrzędnym celem tej Strategii jest petne wykorzystanie zrealizowanych projektów turystycznych $i$ okołoturystycznych dla uzyskania efektów gospodarczych i społecznych wynikajacych z rozwoju turystyki $w$ województwie świętokrzyskim ${ }^{30}$.

\section{Wyniki badań}

Badania na temat rozpoznawalności i oceny działań promocyjnych województwa świętokrzyskiego przeprowadzono w trzecim kwartale 2016 roku. Badanie przeprowadzono za pośrednictwem Internetu i było skierowane do osób pochodzących z całej Polski. W badaniu udział wzięło 238 osób (153 kobiety i 85 mężczyzn). Największą grupę badanych stanowiły osoby w wieku 21-31 lat (66\%). Celem badań była m.in. ocena działań promujących region, a także identyfikacja skojarzeń z regionem i ocena wizerunku regionu. Wszystkie te elementy składają się na markę miejsca. Spośród badanych respondentów, 77 (32\%) osób pamiętało, że spotkało się $\mathrm{Z}$ działaniami promującymi region świętokrzyski. Co prawda $27 \%$ było niepewnych co do tego czy działania, które kojarzą są związane z promocją tego regionu. Formy promocji, które najbardziej zostały zapamiętane przez respondentów to nie tylko reklama w telewizji uwzględniająca typowe spoty reklamowe, ale też programy telewizyjne na

${ }^{30}$ Strategia..., op.cit. s.253, http://www.rot.swietokrzyskie.travel (dostęp 25.09.2017) 
temat regionu (75\%). Ponadto respondenci zapamiętali również billboardy reklamowe $(43 \%)$ oraz reklamę w Internecie $(31 \%)$. Jeśli chodzi o ocenę tych działań to najwyższą ocenę $\mathrm{w}$ skali 1-5, mając na uwadze zachęcenie do przyjazdu do regionu otrzymała reklama w telewizji (ocenę 4 i 5 przyznało łącznie 51 osób). Najwięcej niskich ocen przypisano reklamie $\mathrm{w}$ radiu oraz w prasie, co jednoznacznie świadczy, iż te formy nie były skuteczne w kreowaniu popytu turystycznego i zachęcenia do odwiedzenia regionu. Nikt z osób, które zetknęły się z działaniami promocyjnymi regionu nie kojarzył reklam na autobusach. Otrzymane odpowiedzi zaprezentowano na wykresie 1.

घ $1 \square 3 \square 4 \square 5 \square$ Nie spotkałem/am się z tą formą

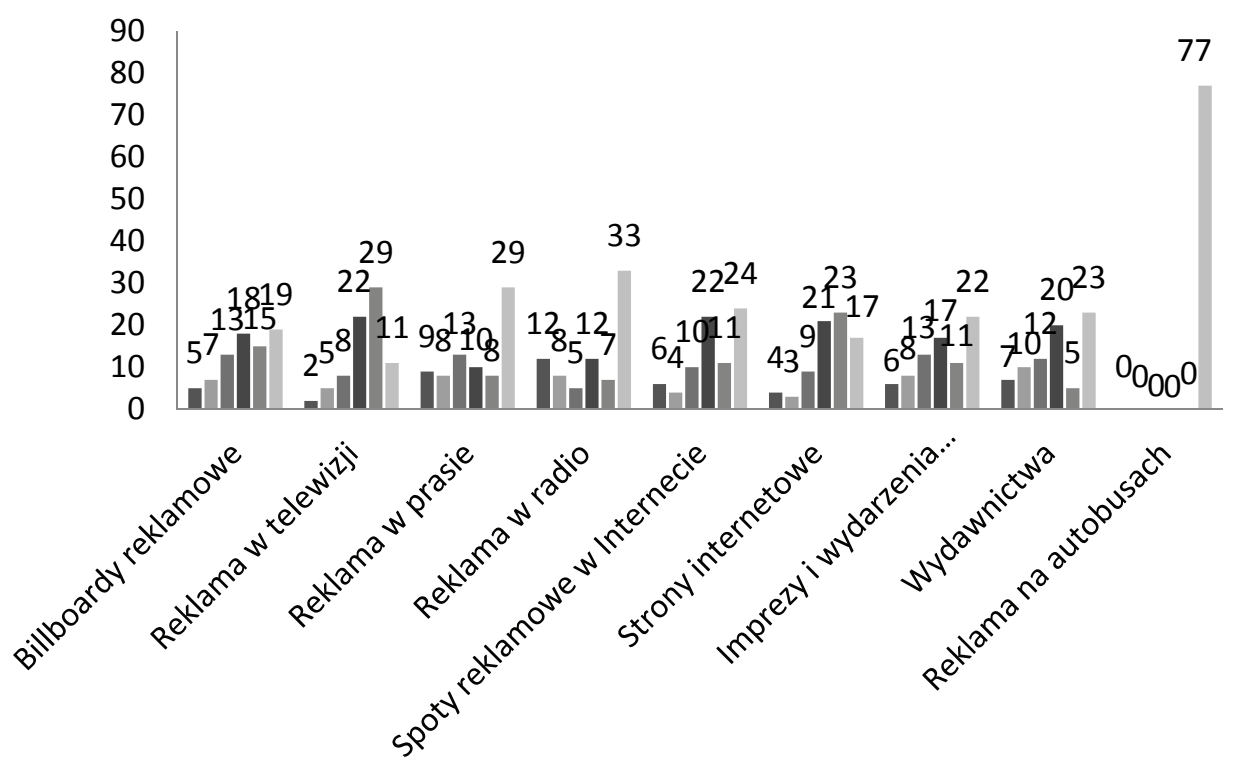

Wykres 1. Ocena poszczególnych form promocji, z którymi zetknęli się respondenci $\mathrm{n}=77$

Źródło: opracowanie na podstawie przeprowadzonego badania.

Średnie oceny jakie uzyskały działania promocyjne w poszczególnych mediach kształtują się następująco: reklama w telewizji - 4,1, reklama w Internecie - 3,5, reklama zewnętrzna $-3,5$, reklama $\mathrm{w}$ prasie $-3,0$, a w radiu $-2,9$. Jeśli chodzi o imprezy promujące region takie jak: Sabat Czarownic, Dymarki Świętokrzyskie, czy Kabaretowe Wakacje z Duchami, otrzymały one średnią ocenę 3,3. Chcąc zbadać rozpoznawalność kampanii promujących region, przedstawiono respondentom zdjęcia 4 billboardów reklamowych, wykorzystanych w kampaniach promocyjnych różnych regionów, w tym województwa lubelskiego, warmińsko-mazurskiego, świętokrzyskiego i śląskiego. Poproszono respondentów o wskazanie rysunku, który jednoznacznie 
kojarzy im się z województwem świętokrzyskim. Połowa respondentów prawidłowo wskazała na billboard województwa świętokrzyskiego, 20\% wskazało na rysunek z kampanii województwa śląskiego, a 15\% wskazało billboard promujący województwo warmińsko-mazurskie jako ten, który jednoznacznie kojarzy im się z badanym regionem. Podobnie uczyniono z logiem regionu, prezentując je wśród logotypów innych regionów. W tym przypadku 70\% respondentów prawidłowo wskazało logo województwa świętokrzyskiego.

Kolejnym elementem badania było zidentyfikowanie skojarzeń z badanym regionem. Otrzymane odpowiedzi zaprezentowano na wykresie 2.

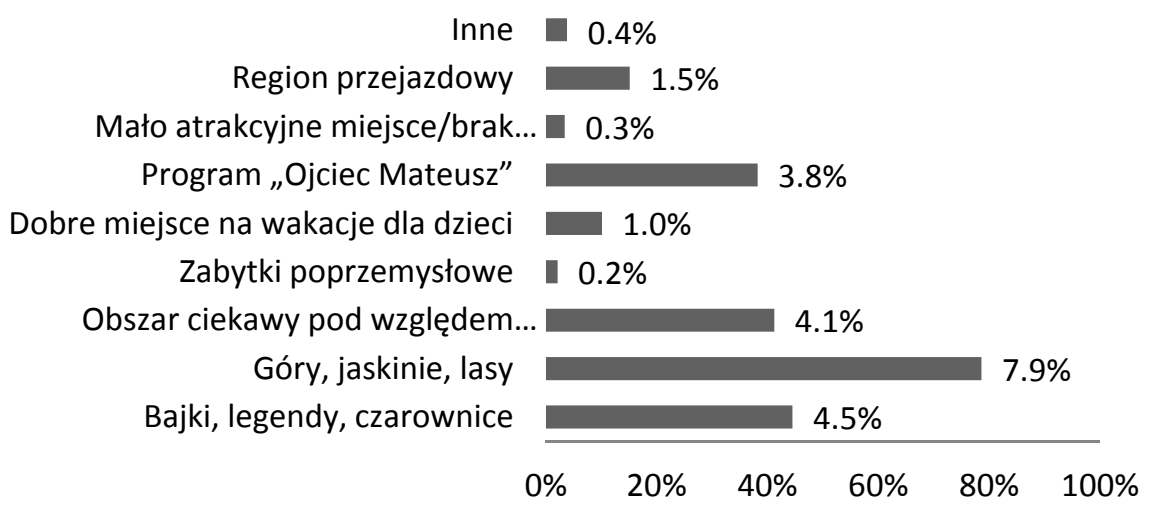

Wykres 2. Skojarzenia dotyczące województwa świętokrzyskiego w opinii badanych Źródło: opracowanie na podstawie przeprowadzonego badania.

Województwo świętokrzyskie najsilniej kojarzy się badanym z górami, jaskiniami i lasami, a więc ze środowiskiem naturalnym $(79 \%$ badanych wybierało tę odpowiedź). W następnej kolejności region kojarzony jest $\mathrm{z}$ bajkami, legendami i czarownicami (45\%), a także $z$ ciekawą geologią regionu (41\%). Równie często respondenci kojarzyli region z serialem „Ojciec Mateusz” (38\%). Skojarzenia negatywne wybierano stosunkowo rzadko. Jedynie 3,4\% badanych postrzega świętokrzyskie jako mało atrakcyjne miejsce lub region o małej liczbie atrakcji. Więcej badanych $(15 \%)$ postrzega województwo jedynie za region przejazdowy, czyli taki, przez który trzeba przejechać, aby dotrzeć do innych atrakcyjnych miejsc (np. do Krakowa, w Bieszczady).

Jeśli chodzi o subiektywną ocenę respondentów dotyczącą wizerunku województwa świętokrzyskiego $\mathrm{w}$ aspekcie jego zmiany $\mathrm{w}$ ciagu ostatnich lat, warte podkreślenia jest, że blisko $60 \%$ respondentów uważa, że wizerunek regionu poprawił się, przy czym $41 \%$ udzieliło odpowiedzi, że wizerunek zdecydowanie poprawił się, a blisko $18 \%$ stwierdziło, że raczej poprawił się. Jedna trzecia respondentów nie miała w tej kwestii własnego zdania, udzielając odpowiedzi „nie mam zadania”, a pozostałe 8\% stwierdziło, że poprawa wizerunku nie wystąpiła. Respondenci zostali poproszeni również o odpowiedź na pytanie: Czy uważa Pan/Pani, że przeprowadzenie kampanii promocyjnej regionu przyczyni się do wzrostu liczby osób odwiedzających region? Niestety połowa respondentów nie miała zdania na ten temat, 12\% odpowiedziało, że raczej tak, 28\%, ze zdecydowanie tak. 
Formalnie kampania promocyjna zakończyła się w 2013 roku, można więc na podstawie danych statystycznych ocenić czy faktycznie nastąpił wzrost liczby turystów odwiedzających region. Jako kluczowy należy w tym względzie uznać rok 2008 czyli początek kampanii promocyjnej regionu, rok 2013 jako czas zakończenia kampanii oraz kolejne lata aby móc ocenić czy wystąpił długotrwały efekt kampanii, objawiający się wzrostem liczby przyjazdów turystycznych do regionu. Według danych Instytutu Turystyki, przyjazdy turystów krajowych do województwa wyniosły w 2008 roku $1,1 \mathrm{mln}$, w tym $0,4 \mathrm{mln}$ stanowiły przyjazdy długookresowe, a $0,7 \mathrm{mln}$ przyjazdy krótkookresowe $^{31}$. W 2013 roku liczba przyjazdów turystów krajowych wyniosła 1,7 mln czyli nastapił ponad 50\% wzrost liczby przyjazdów w stosunku do roku bazowego (0,6 mln przyjazdy długookresowe i $1,1 \mathrm{mln}$ przyjazdy krótkookresowe). Według danych GUS w 2015 r. krajowy ruch turystyczny w województwie świętokrzyskim wyniósł $0,94 \mathrm{mln}$ podróży. Podróże krótkookresowe stanowiły prawie $0,57 \mathrm{mln}$, zaś długookresowe $0,37 \mathrm{mln}^{32}$. Na podstawie powyższych danych można jednoznacznie stwierdzić, że przeprowadzona kampania promocyjna przyczyniła się do wzrostu popularności regionu świętokrzyskiego, gdyż w roku 2013 mamy wysoki wzrost liczby przyjazdów turystów w stosunku dla roku 2008, kiedy to rozpoczynano kampanię promocyjną. Jednakże, jak widzimy na podstawie danych, efekt ten nie utrzymał się zbyt długo i w 2015 roku liczba przyjazdów turystycznych wyraźnie spadła. Z tego faktu wypływa wniosek dla wszystkich podmiotów odpowiedzialnych za promocję regionów, że działania te aby przynosiły efekty muszą być prowadzone niemalże w sposób ciagły, gdyż w przeciwnym razie turyści szybko o danym regionie zapominają i na miejsce swoich wyjazdów wybierają inne, lepiej rozpoznawalne miejsca.

\section{Podsumowanie}

Marketing terytorialny to współczesna koncepcja zarządzania miastami, regionami, a nawet całym państwem. W Polsce jego zastosowanie dopiero się rozwija, a najszerzej wykorzystywanym jego narzędziem jest promocja. To właśnie głównie dzięki działaniom promocyjnym możliwe jest wykreowanie marki danego miejsca. Przykładem regionu, który prowadzi taką aktywność jest z pewnością województwo świętokrzyskie. Województwo świętokrzyskie ma duży potencjał turystyczny, który z powodzeniem może wykorzystać w przyszłych kampaniach promocyjnych. Co więcej, przy realizacji kolejnych działań promocyjnych region może wykorzystać szeroki wachlarz najnowszych narzędzi i form promocji. Przeprowadzona kampania promocyjna województwa świętokrzyskiego to świetny przykład kreatywnej i skutecznej promocji regionu. Jest to wzór, na którym mogą się opierać inne regiony. Jest to szczególnie interesujące studium przypadku pokazujące, jak duże znaczenie dla kreowania marki regionu ma odpowiednia promocja turystyczna. Działania te muszą być jednak długotrwałe, gdyż zbudowanie wizerunku i marki miejsca wymaga wielu lat ciężkiej pracy i wysokich nakładów finansowych. Można w tym miejscu przytoczyć słynne

${ }^{31}$ Turystyka polska w 2008 roku. Układ Regionalny. Instytut Turystyki sp. z o.o., Warszawa 2009

${ }^{32}$ Turystyka w 2015 roku. Informacje i opracowania statystyczne. Główny Urząd Statystyczny, Warszawa 2016 
słowa Warrena Buffeta, który stwierdził, że dwadzieścia lat trwa budowanie reputacji, a tylko 5 minut jej zrujnowanie.

\section{Bibliografia}

Turystyka polska w 2008 roku. Układ Regionalny. Instytut Turystyki sp. z o.o., Warszawa 2009.

Turystyka w 2015 roku. Informacje i opracowania statystyczne. Główny Urząd Statystyczny, Warszawa 2016. Strategia rozwoju turystyki $w$ województwie świętokrzyskim na lata 2014-2020, http://www.rot.swietokrzyskie.travel (dostęp: 25.09.2017).

Aleksander A., Sworowska A.: Ksztaltowanie tożsamości jako element działań marketingowych regionu. [w:] J. Koszałka (red.): Marketing. Ujęcie Terytorialne. Wyd. Wydział Zarządzania i Ekonomii, Politechnika Gdańska, Gdańsk 2010.

Baloglu K.W., McCleary A.: Model of destination image formation, "Annals of Tourism Research", 1999, nr 26(4), 868-897.

Brelik A.: Marketing terytorialny a kreowanie regionów, „Zeszyty Naukowe SGGW WNE Polityki Europejskie, Finanse i Marketing", Wyd. SGGW, 2010, nr 3 (52), 322-328.

Castronovo C., Huang L.: Social media in an alternative marketing communication model. „Journal of Marketing Development and Competitiveness". Wyd. North American Business Press, 2012, Vol. 6, No. 1, 117-134.

Chrząścik M.: Teoretyczne ujęcie promocji w aspekcie koncepcji marketingu terytorialnego. Zeszyty Naukowe Uniwersytetu Przyrodniczo-Humanistycznego w Siedlcach. Seria „Administracja i Zarządzanie”. Wyd. Uniwersytetu Przyrodniczo - Humanistycznego w Siedlcach, 2012, Nr 94, 143-151.

Dudek-Mańkowska S., Balkiewicz-Żerek A.: Siła marki miejsca, „Marketing i Rynek” nr 6, 2015, 14-23.

Ferris M.: Insights on mobile advertising, promotion, and research. „Journal of Advertising Research”, 2007, Vol. 47, No. 1, 28-37.

Florek M.: Podstawy marketingu terytorialnego. Wyd. Akademii Ekonomicznej, Poznań 2006.

Furman W.: Public relations - skuteczny instrument budowy wizerunku jednostki terytorialnej, w: K. Kaszuba (red.) Marketing w zarzadzaniu rozwojem lokalnym, Białystok: Fundacja Kształcenia Kadr, 2010.

Gębarowski M.: Nowoczesne formy promocji. Wyd. Oficyna Wydawnicza Politechniki Rzeszowskiej, Rzeszów 2007

Glińska E., Florek M., Kowalewska A.: Wizerunek miasta: od koncepcji do wdrożenia, Wolters Kluwer, Warszawa 2009

Kołomycew A.: Promotion in the agenda of public administration (the case of the communes in the Tarnobrzeg district). „Polityka i Społeczeństwo”. Wyd. Uniwersytetu Rzeszowskiego, 2010, nr 7.

Kotler Ph.: Marketing Management, Analysis, Planning, Implementation and Control. Wyd. Prentice Hall, Englewood Cliffs, Nowy Jork 1994.

Kotler Ph., Philip Kotler odpowiada na pytania na temat marketingu, Dom Wyd. Rebis, Poznañ 2004.

Łazorko K. (red.), Niedzielska A. (red.): Kreowanie wizerunku miejsca w koncepcji marketingu terytorialnego. Seria Monografie nr 207. Wyd. Politechniki Częstochowskiej, Częstochowa, 2011.

Malacka L.: Current trends in marketing communication and their application to Tourism.https://www.researchgate.net/publication/277304941 CURRENT TRENDS IN MARKETING CO MMUNICATION_AND_THEIR_APPLICATION_TO_TOURISM (dostęp: 15.09.2017).

Panasiuk A.: Marketing ustug turystycznych. Wyd. Naukowe PWN, Warszawa 2007.

Peszko K.: Event marketing jako efektywne narzędzie komunikacji marketingowej. „Zeszyty Naukowe

Uniwersytetu Ekonomicznego w Poznaniu", Wyd. Uniwersytetu Ekonomicznego w Poznaniu, 2010, nr 136, 164-172.

Rumpel P., Siwek T.: Marketing terytorialny a kreowanie regionów: przyklad czeski. „Przegląd Geograficzny". Wyd. PAN IGiPZ, 2006, t. 78, z. 2, 191-205.

Santos S.: 2012\&2013 social media and tourism industry statistics. www.stikkymedia.com/blog/2012-2013social-media-and-tourismindustry-statistics - (dostęp 15.09.2017).

Sobczyk G., Celoch A.: Marketing współczesnej organizacji. [w:] D. Filar (red.): Współczesny marketing. Skuteczna komunikacja i promocja. Wyd. UMCS, Lublin 2012.

Szromnik A.: Targi w rozwoju miast i regionów. [w:] H. Mruk (red.): Znaczenie targów dla rozwoju gospodarczego kraju. Wyd. PIPT, Poznań 2011, 37-57. 
Szromnik A.: Marketing terytorialny jako atrybut rynkowej orientacji miast oraz regionów. [w:] A. Grzegorczyk (red.), A. Kochaniec (red.): Kreowanie wizerunku miast. Wyższa Szkoła Promocji, Warszawa 2011.

Szromnik A.: Strategia city placement $w$ systemie innowacji marketingowych $-c z$. 1. „Marketing i Rynek”. Wyd. PWE, 2015 nr 8, 5-14.

Truong Y., Simmons G.: Perceived intrusiveness in digital advertising: strategic marketing implications. „Journal of Strategic Marketing”. Wyd. Taylor \& Francis, 2010, Vol. 18, No. 3, 239-256.

Zickuhr K., Smith A.: 28\% of American adults use mobile and social location-based services. www.pewinternet.org/2011/09/06/28-of-american-adults-use-mobile-and-social-location-based-services/ (dostęp 15.09.2017)

\begin{abstract}
The article presents the theoretical aspects related to territorial marketing, focusing especially on the instrument of promotion. Currently the term promotion is a very broad one and in terms of it we have the possibility to take advantage of various tools, both traditional and nonstandard ones. The popularity of the latter results to a large degree from the changes in consumer behaviors caused for example by the development of the Internet, including social media, blogs, etc. The terms of promotion, brand, and image are used today in reference not only to goods and companies, but also locations, meaning regions, cities, voivodeships, or communes.

The goal of this article is to present the wide spectrum of promotion activities which have been executed in the Świetokrzyskie Voivodeship, as well as to determine the effects of these actions in quantitative and image-related aspects. Furthermore, the level of recognizability has been researched in terms of promotion campaigns and their relation with the analyzed region. A research taking advantage of an online survey questionnaire has been used in order to execute the above presented goals. The research group consisted of 238 respondents from all over Poland, who have filled out the survey voluntarily. The research results confirm the need for promotional activities in the regions as these actions have an impact on creating the region's image, increasing the number of tourists visiting a given region, and despite a large "information noise" these actions are remembered by the recipients.
\end{abstract}

Key words: territorial marketing, tourism promotion, place image, place brand, świętokrzyskie voivodeship

Informacje o autorze:

dr inż. Marzena Lemanowicz

Szkoła Główna Gospodarstwa Wiejskiego w Warszawie, Wydział Nauk Ekonomicznych

Katedra Polityki Europejskiej i Marketingu, e-mail: marzena_lemanowicz@sggw.pl 